\title{
VIP Peptides
}

National Cancer Institute

\section{Source}

National Cancer Institute. VIP Peptides. NCI Thesaurus. Code C136790.

VIP peptides (170 aa, $\sim 19 \mathrm{kDa}$ ) is encoded by the human VIP gene. This protein plays a role in the regulation of vasodilation. 